\title{
INTERNATIONAL STUDENTS CONTRIBUTION TO BUSINESS SCHOOLS IN THE UK HEIs
}

\author{
Trevor Uyi OMORUYI*1, Grazyna REMBIELAK ${ }^{1}$, Agnieszka PARLINSKA ${ }^{2}$
}

\author{
Address: \\ ${ }^{1}$ Business and Management, Salford Business School, The University of Salford, Manchester, Maxwell Building, University of Salford, Salford M5 \\ 4WT; UK \\ ${ }^{2}$ Warsaw University of Life Sciences, Faculty of Economic Sciences, Department of European Policy, Public Finance and Marketing; \\ Nowoursynowska 166 St. 02-787 Warsaw; Poland; \\ *Corresponding author: t.u.omoruyi@edu.salford.ac.uk
}

\begin{abstract}
International students' contribution to Higher Education Institutions (HEIs) tends to be considered from different aspects. There is an inadequate substantiation base that would allow academics, researchers and other stakeholders understand the importance of overseas students in the UK Business Schools. This paper investigates the contribution of international students to Business School in the UK HEIs.

The research was exploratory and part of a bigger project on how and why Business Schools in the UK use Relationship Marketing to retain international students. It employed semi-structured interviews with 18 members of staff from four Business Schools in the North of England.

Findings indicate that international students' definition tends to differ amongst staff members within the Business Schools. Business Schools' management perceive overseas students as an integral part of their institutions, especially as their overall contributions cannot be over-emphasised.

The sample size and use of semi-structured interviews, as a single data gathering strategy, does not allow broad generalisation of findings. The obtained evidence can still be used as a platform for further research in this area.
\end{abstract}

Keywords: Higher Education, International students, Business Schools, United Kingdom

JEL: R52, R58, H41

\section{INTRODUCTION}

There has been a significant growth in the number of Business Schools over the last decade within the UK HEIs and a large number, if not all of these Business Schools, have focused on internationalisation. A substantial amount of publications have shown how international students contribute to different economies of their study destination in different countries amongst the developed nations (for example, among others, Abbott \& Doucouliagos, 2009; Brown \& Mazzarol, 2009). Only a few of these publications focus mainly on how overseas students contribute to Business Schools. Business Schools within the UK tend to enrol more overseas students as compared to other faculties (HESA, 2001). There has been a significant gap in establishing how international students contribute to Business Schools within the UK HEIs. It was reported in 2012/2013 that the UK HEIs have non-UK domiciled students of 425,265 where 299,975 was from outside other European Union (EU) region states (HESA, 2014). From the numbers of international students in the UK HEIs, Business Schools have a greater percentage of overseas students.

With the enormous presence of international students in the UK Higher Education, their contribution to the UK economy, their contribution to profiles of UK HEIs and contribution to businesses and individuals in the UK, it is imperative and timely that research on what and how they contribute to faculties be well understood. In addition, a good understanding of who overseas students are should be clearly defined so as to help address how they are perceived across the spectrum of all levels of management within the University. In the light of the theoretical base of this paper the purpose is to investigate how international students contribute to Business Schools in the UK HE sector.

\section{LITERATURE REVIEW}

The UK has been found to be the second most popular study destination for international students after the United States. There has been a rapid growth of 34\% in overseas students coming to study in the UK between 2000 and 2012 and a huge chunk of these numbers tend to fall within the Business Schools. Where the income that comes from the overseas students in Business Schools tends to be what the universities heavily rely upon (Starkey et al., 2004). International students are identified to be higher in international business education programmes, international students even outnumber local students in some Business Schools (Rienties et al., 2012). It can be seen that the Business School is the faculty amongst others in the UK HEI that have more international students. The Business School in the UK happens to be a popular choice amongst international 
students (Vargo-Atkins, 2004). The international structure of the faculty members have also seen significant growth in recent times. This can be argued as a result of the growth in the number of international students in the UK business schools.

The term international student is a term used to replace foreign students (Arthur \& Nunes, 2014). Students who leave their home countries to study abroad are known as international students. More than three million students leave their countries to study primarily at a Western university (Rienties et al., 2011). Western universities host a significant number of international students (Smith \& Khawaja, 2011). HEIs around the globe are gearing efforts towards how to enrol a large share of these international students. $10 \%$ of these international students are reported to be in the UK HEIs (OECD, 2010). The growing number of international students in the UK has gained the attention of educators and researchers (Wang, Hardy \& Mai, 2012). In the UK the distinction may be made on the basis of fee status, so 'home' students in that sense can include other European Union (EU) students, whereas in other contexts 'international' students include non-UK EU students. Domicile can also be used to define international students (Binsardi \& Ekwulugo, 2003).The Erasmus students in this study was not considered as international students, considering the fact that the Universities involved in the Erasmus programme are mainly EU universities.

The overall economic impact of these international students goes beyond their contribution to the host university to the UK economy (Love \& McNicoll, 1988). Increase in the number of full-fee overseas students has contributed immensely to the financial growth of UK Universities (Turner, 2006). The fees for international students and EU students are different. British Universities earn more money as tuition from international students as the tuition to be charged from home students is capped at a rate of $£ 9000$ a year.

International students do not serve only as a source of revenue for HEIs, they also enhance classroom discussions following the valuable insights they contribute (Frederick, 1995). International students also enrich the learning environment with their different heritage and perspectives, hence, serving to improve cultural awareness and appreciation (Harrison \& Peacock, 2010). International students bring a variety of benefits to the host country (Smith \& Khawaja, 2011). These international students make valuable educational and economic contributions to English-speaking countries (Andrade, 2006).

\section{MATERIAL AND METHODS}

In conducting this study, which is an exploratory study, the qualitative approach and the semi-structured interview method of collecting data were used. Interviews were conducted with Deans of Business Schools, Academic Deans, and International Marketing Directors, and members of academic staff, who carry out the delivery, and Programme Leaders. Interview topics were depicted from literatures reviewed. Questions also included demographics such as age of the business school, position held, and number of international students. A case study research strategy was adopted in this study.

\section{Selection of Participants and Data Analysis}

The target population of this study was Business Schools in the Greater Manchester area that enrols a large number of international students. The subjects for the study were Deans/Directors of Business Schools, Academic Deans and Programme Leaders. All of these are identified as the top and key players of the Business Schools. A second phase of the interview was conducted with academics that carry out the delivery to international students in the Business Schools. The interviews were face-to-face semi structured ones, which lasted for an average of forty five minutes to one hour each. The Business Schools were selected from "red brick" universities, Pre-92 and Post 92 universities in the UK HEIs. The Greater Manchester was selected knowing that it has the largest number of international students in Europe. Data was also collected from other sources which include documentation, observation and archival records. Data collected were analysed using content analysis and rigour was taken to ensure its validity and triangulation.

\section{RESULTS AND DISCUSSION}

The study found that there is no one agreed definition of international students amongst the interviewees. Definition of international students falls within different categories (Fee status, Non-UK students, Non-EU students, students who do not speak English as their first language, educational background of the students). These are categories of the definition of international students found from respondents. There was a huge difference within the way they were defined by the management and the way they are defined by the academic staff that carry out the delivery. Where the key players generally defined international students as students who are NonUK and Non- EU students who are expected to pay a higher fee, academic staff generally described international student as students for whom English is not the first language, and others especially the academic staff defined them as students who lack UK educational background.

The study also found that international students' contribution to Business Schools is quite massive and from the respondents, it was found that within and outside the classroom their contribution cannot be over emphasised. Some of the contributions found were grouped into several categories (Income, Diversity, Enhanced Curriculum, Multicultural Environment, Reputation, Collaborative Research, Value, Social Mobility and International exchanges). The study found that apart from the revenue brought in by international students, the international students also bring about a dynamic and vibrant environment in terms of diversity. It was found that class participation and class debate becomes robust as a result of several experiences and 
examples from international students. It was also found that the presence of qualified international students in the Business School also helps to give the business school a great reputation in the global Higher Education market. The presence of international students also gives the opportunity for international research, partnerships and collaboration.

\section{CONCLUSION}

The study has investigated the contributions of international students to Business Schools in the UK Higher Education sector. The semi structured interviews conducted with the interviewees were based on the framework of the study, which was pilot tested. The study identified that they were a number of dissimilarities amongst the number of international students in the case of study organisation. The relatively new Business Schools, with not yet established reputation in the global education market, tend to enjoy less the patronage and contribution of international students as compared to the Business Schools, which are already well established.

The findings of the study have added to the body of knowledge that international students contribute immensely to Business Schools, HEIs, and the host country in general. It is interesting to note that contrary to some publications that tend to undermine the contributions of international students to their host country, the contributions of international students to the UK economy cannot be over emphasised.

One area of significance is the difference in the definition of international students between the key players, who do not have a direct contact with the international students, and the academic staff, who carry out the delivery. The academic staff define them in terms of their contribution to class participation and the consideration of challenges they might face which include not speaking English as a first language and their previous educational background which is likely to be different from that of the UK.

It can be concluded that enrolling and retaining a large number of international students are one of the core focuses of Business Schools in the UK. International students' contribution is massive and the Business Schools value them not just because of their financial contribution but also because of their contribution in terms of the development of the Business School and the development of other students in the Business School. Business Schools' management perceive international students as an integral part of their institutions, especially as their overall contributions cannot be over-emphasised. It was also found that international students are more popular within the Business Schools as compared to other schools in the UK HEIs where several reasons were identified for this dominance.

Hence, it is important that Business Schools should continue to develop the appropriate marketing strategy that will help them achieve their core aims.

Based on the study it can be recommended that Business Schools should consider the overall importance of international students and endeavour to establish a long lasting relationship with them. It can be also recommended that Business Schools should consider the challenges of international students in their schools and provide adequate support to mitigate these challenges.

The Business Schools should continue to advocate for the Government to consider the importance of international students to UK HEIs and the UK economy in general so as to encourage the Government to provide flexible and welcoming policies that will cater for international students.

Further research can be carried out using evidence from this study to identify how international students' recruitment and retention can be enhanced. Other studies could also consider challenges faced by international students using evidence from this study to analyse the cost benefit implication of proffering adequate solutions to such problems, findings, possible solutions to the problem, recommendations for further research, etc.

\section{REFERENCES}

ABBOTT, M. - DOUCOUliAgOS, C. 2009. Competition and efficiency: overseas students and technical efficiency in Australian and New Zealand universities. Education Economics, 17(1), 31-57. http://dx.doi.org/10.1080/09645290701773433

ANDRADE, M. S. 2006. International students in English-speaking universities Adjustment factors. Journal of Research in International Education, 5(2), 131-154. http://dx.doi.org/10.1177/1475240906065589

ARTHUR, N. - NUNES, S. 2014. Should I stay or should I go home? Career guidance with international students. In Handbook of Career Development (pp. 587-606). Springer New York. http://dx.doi.org/10.1007/978-1$\underline{\text { 4614-9460-7_33 }}$

BINSARDI, A. - EKWULUGO, F. 2003. International marketing of British education: research on the students' perception and the UK market penetration. Marketing Intelligence \& Planning, 21(5), 318-327.

BROWN, R. M. - MAZZAROL, T. W. 2009. The importance of institutional image to student satisfaction and loyalty within higher education. Higher Education, 58(1), 81-95. http://dx.doi.org/10.1007/s10734-0089183-8

FREDERICK, P. 1995. Walking on eggs: Mastering the dreaded diversity discussion. College Teaching, 43(3), 83-92.

http://dx.doi.org/10.1080/87567555.1995.9925522

HARRISON, N. - PEACOCK, N. 2010. Interactions in the International Classroom. Internationalisation and the student voice: Higher education perspectives, 125.

HIGHER EDUCATION STATISTICS AGENCY 2001

LOVE, J. - MCNICOLL, I. 1988. The Regional Economic Impact of Overseas Students in the UK: A Case Study of Three Scottish Universities. Regional Studies, 22(1), 11-18. http://dx.doi.org/10.1080/00343408812331344730

OECD 2009a, International Assessment of Higher Education Learning Outcomes (AHELO) Feasibility Study, www.oecd.org/edu/ahelo , accessed 1 February 2009. 
RIENTIES, B. - BEAUSAERT, S. - GROHNERT, T. NIEMANTSVERDRIET, S. - KOMMERS, P. 2012. Understanding academic performance of international students: the role of ethnicity, academic and social integration. Higher education, 63(6), 685-700.

SMITH, R. A. - KHAWAJA, N. G. 2011. A review of the acculturation experiences of international students. International Journal of Intercultural Relations, 35(6), 699-713. http://dx.doi.org/10.1016/j.ijintrel.2011.08.004 STARKEY, K. - HATCHUEL, A. - TEMPEST, S. 2004. Rethinking the Business School. Journal of Management Studies, 41(8),

1521-1531. http://dx.doi.org/10.1111/j.1467-6486.2004.00485.x
TURNER, Y. 2006. Chinese students in a UK business school: Hearing the student voice in reflective teaching and learning practice. Higher Education Quarterly, 60(1), 27-51. http://dx.doi.org/10.1111/j.14682273.2006.00306.x

VARGA-ATKINS, T. - ASHCROFT, L. 2004. Information skills of undergraduate business students-a comparison of UK and international students. Library Management, 25(1/2), 39-55.

WANG, Y., HARDING, R. - MAI, L.W. 2012. Impact of cultural exposure on young Chinese students' adaptation in a UK business school. Studies in Higher Education, 37(5), 621-639. 